\title{
Amirthathi Churnam and Nandukal Chunnam of Siddha Formulation and Clinical Evaluation of Nephrolithiasis
}

\author{
Eleza Chellakkan ${ }^{1}$, Chandrasekar Nainarpandian ${ }^{2 *}$, Finney Blessed ${ }^{3}$ and Victor Rajamanickam \\ Gnanamanickam ${ }^{4}$ \\ 1,3Siddha Consulting Centre, Sarakalvilai, Tamil Nadu, India \\ ${ }^{2}$ Medical Geology Laboratory, Centre for GeoTechnology, Manonmaniam, Sundaranar University, India
}

${ }^{4}$ Vels University, Tamil Nadu, India

Submission: January 30, 2017; Published: August 03, 2018

*Corresponding author: Chandrasekar Nainarpandian, Professor and Head, Medical Geology Lab, Centre for GeoTechnology, Manonmaniam Sundaranar University, Tirunelveli 627012, Tamil Nadu, India, Tel: +91- 94-4316-2820; Email: profncsekar@gmail.com

Abstract

Introduction: Siddha system of medicine is one of the most accepted traditional system of medicine in India. This system provides innumerous dosage of drug formulations from the herbal plant mentioned in the Siddhar"s literature. The present study represents the preparation and formulation of Amirthathi churnam and Nandukal (Fossil stone of Crab) chunnam of Siddha drugs in the treatment of Nephrolithiasis (urinary stones). The highly commended medicine formulation of churnam (power) and chunnam (calcinated nanoparticle powder) in Siddha medicine system is comprehensively used in the drug preparation and therapeutic effects. Churnam is a mixture of powdered herbs and or minerals used in Siddha and Ayurvedic medicine. Chunnam is highly acclaimed dosage form of alkaline group of drugs indicated for chronic diseases.

Methodology: The preparation of Amirthathi churnam is performed from the 25 herbal plants and camphor chemical substance. The roots, leaves, barks, woods, fruits, seeds, flower, rhizomes and nutlets of the plants are dried and pulverized to $0.004 \mathrm{~mm}$ (powder particle size) to produce Amirthathi churnam as per the Pala Thiratha Chuvadi (Tamil medicine literature written in palm leaves). Similarly the Nandukal chunnam is formulated from the pooneeru and lime water. After purification of this extract, the Aolevera latex is mixed with the formulation and calcinated as per the procedure of Agasthiar Nandukal Sootheram (method of formulation).

Results: The efficacy of Amirthathi churnam and Nandukal chunnam have been carried out by the clinical trial for 20 patients between the age 15 and 75. The urinary tracts stones are causing renal morbidity due to the presence of citrate ions in urine which forms soluble complex with $\mathrm{Ca}+$ and $\mathrm{Mg}+$. The clinical test of these formulations against treatment of Nephrolithiasis reveals the recovery of renal calculus (77\%), ureteric calculus $(80 \%)$ and vesicle calculus (50\%). Hence, the use of Amirthathi churnam and Nandukal chunnam has shown effective results in the management of urinary tract stones by excretion of citrate ions. The chemical analysis of the drug shows that the elements are within the World Health Organization (WHO) recommended limits. It is observed that these formulations would reduce the citrituric effect for long life span.

Discussion: The role of the above prepared drug used as a lithotripic agent in about 20 patients with Nephrolithiasis. The clinical evaluation reveals that the symptom of burning micturalion, dyuria, Hematuria, abdominal pain from loin to groin, Back pain, and general symptoms like nausea and vomiting reduced significantly in all the patients. This indicated the positive results to remove the urinary stones. The $99 \%$ of patients having $0.5 \mathrm{~mm}$ size of the calculi have been recovered after the periods of treatment.

Conclusion: The drugs namely Amirthathi churnam and Nuandukkal chunnam are having good response to reduce the size of the calculi. The clinical studies of these drugs provide positive results to remove the urinary stones. After having treatment, the patients have been found with non-recurrent condition. It is observed that the Amirthathi churnam and Nuandukkal chunnam in Siddha formulations are considered to be safe for treating the Nephrolithiasis diseases.

Keywords: Siddha medicine system; Urinary stone; Amirthathi Churnam; Nuandukkal Chunnam; Nephrolithiasis

Abbreviations: ADI: Acceptable Daily Intake; AAS: Atomic Absorption Spectro-photometry; WHO: World Health Organization

\section{Introduction}

Siddha is a traditional medical system of Tamil Nadu since ancient periods to present. The formulation of Siddha medicine is purely from Tamil origin and its entire medicine procedure is available in Tamil language [1]. Siddha medicine system uses herbs and their anatomical parts for extraction of metals and minerals for curing different ailments such as varieties of joint diseases, skin diseases, liver problems and urinary tract infections [2]. Urinary stone is known since long and has several factors for formation in the human body. The urinary stone in the kidney is due to formation of calcium oxalate monohydrate and basic calcium phosphate [3]. It is one of the oldest diseases found in the worldwide. For example, the urinary calculi have 
been found even in the tombs of Egyptian mummies dating back to $4000 \mathrm{BC}$ and also in the graves of North American Indians belong to 1500-1000 BC [4]. In the ancient world, many remedies have been employed during the ages to treat urinary stones in the traditional system of medicine. The traditional medicine system uses the numerous medicinal plants and their formulations for treating diseases in ethno- medical practices [5]. In India, the herbo-mineral treatment is widely used for urinary diseases effectively without side effect and this can be achieved as alternative medicine to the modern treatment systems [6,7]. In Siddha medicine system, food is a medicine as one of the ideological treatments and hence, rice is used as food grains for many people because of its nutrition contents like carbohydrates, proteins and minerals which increase immunity of human body [8]. The churnam (powder of herbal extract) and chunnam (calcinated nanoparticle powder) contain preserved mineral extracts and are used to heal the body from decomposing materials which do not decompose easily [9]. For example, the muppu extract has significant role in Siddha medicine system for rejuvenative treatments and antioxidant purposes [10].

Moreover, the churnam and chunnam is effectively eliminating the heavy metals and enrich the elements. It also enhances the therapeutic potential and safety of the drug administrated for healing the chronic diseases [11]. Standardization of herbal formulations based on Siddha system is essential to assess the quality of drugs for healing processes [12]. The preparation of the herbal drug like churnam and chunnam in Tamil traditional medicine is related to theories of palm leaves literature that subject to herbal medicines and their relationship with human physiology and mental function [2]. The churnam is a product of poly herbal used as in urinary tract stone, carminative, antispasmodic treatments in the Siddha medicine system [1]. Further, the chunnam is a drug formulation of Nandukal (fossil stone) extract, pooneeru and calcium hydroxide (slaked lime) in the form of powder used for freshen the breathe urinary diseases and healing the body pain $[13,14]$. Significant researches are carrying out in the present day to explore medicinal usage of herbals in worldwide. The World Health Organization (WHO) has also recognized medicinal importance of the herbo- mineral drugs for public health care in developing nations and encourages the guidelines of standardization and formulation in the traditional medicine for potential usefulness, safety and efficacy [15]. The present study describes the systematic formulation methods of traditional Siddha drug such as Amirthathi churnam and Nandukal chunnam and aims to highlight the efficacy of these drugs for the treatment of nephrolithiasis problems in human bodies.

\section{Materials and Methods}

Siddha drugs like churnam and chunnam are commonly made up of poly-herbal products. Various plant parts have been used as ingredients in the drug formulations. Further, standardization processes of herbal formulations are essential to assess the quality of drugs based on of their active principles of concentrations includes organoleptic characters, physical characteristics, and physico-chemical properties. The systematic procedure for preparation of churnam and chunnam is derived from the palm leaves literature of Siddha medicine system so as evaluate the efficacy in nephrolithiasis treatments through clinical observations.

\section{Preparation of Amirthathi churnam}

Amirthathi churnam consists of 25 herbal ingredients of roots, barks, stem, fruits, leaves, rhizomes, nutlets, flower pistils, dried stigmas, resins or latex etc and the camphor chemical substance. The chemical elements like metals and trace elements of the herbal plants are used for curative and preventive activities in combatting diseases $[16,17]$. The details of common names, botanical names, anatomical parts and quantities are given in the Table 1 . All these ingredients were purchased from the traditional herbal product shops in Tamil Nadu state, India [18]. Whereas in the Ayurvedic medicine system, the preparation of amirthathi churnam consists of five ingredients namely Tyinospora cordifolia, Salacia prenoides, Curuma longa, Trubulus terrestris and Phyllanthus emblica, the constituent drug of these ingredients is administered to diabetic patients [19]. The churnam is prepared as per the procedure of the famous palm leaf literature of Siddha Medicine System known as "Pala thiratha chuvadi" (Ancient Tamil literature written in palm leaf). According to the literature, the ingredients were dried and pulverized to less than $0.004 \mathrm{~mm}$ particles (finely grained) separately (Figure 1) and mixed all the ingredients together in a specified proportions of blended churnam $[20,21]$.

Table 1: The herbal plants ingredients used for preparation of Amirthathi churnam.

\begin{tabular}{|c|c|c|c|c|}
\hline Sl. no & $\begin{array}{c}\text { Name of the Ingredients } \\
\text { in Tamil }\end{array}$ & $\begin{array}{c}\text { Botanical Name or } \\
\text { Chemical Name }\end{array}$ & Anatomical Part Used & Quanitity Used (g) \\
\hline 1 & Vettiveru & Vetiveria zizanodes $L$. & Root & 70 \\
\hline 2 & Talishapattiri & Cinnamomum tamala & Leaf & 70 \\
\hline 3 & Nelli & Phyllanthus emblica $L$. & Seed & 70 \\
\hline 4 & Ilantai & Ziziphus jujuba (L) La $m$. & Seed & 70 \\
\hline 5 & Elakkai & Elettaria cardamomum & Seed & 70 \\
\hline 6 & Drakshai & Vitis vinifera L. & Dried fruit & 70 \\
\hline 7 & Atimaduram & Glycyrrhiza glabra L. & Root & 70 \\
\hline 8 & kungguma poo & Crocus sativus & Flower pistils, Dried \\
stigmas & \\
\hline
\end{tabular}


Journal of Complementary Medicine \& Alternative Healthcare

\begin{tabular}{|c|c|c|c|c|}
\hline 9 & Sirunagappoo & Mesua ferrea & Flower & 70 \\
\hline 10 & Thamarai & Nelimbo nucifera & Rhizomes & 70 \\
\hline 11 & Sandhana maram & Santalum album $L$. & Wood & 70 \\
\hline 12 & chiru peelai & Aerva lanata (L.) Juss & Root & 70 \\
\hline 13 & $\begin{array}{c}\text { Sathavari (Thanneervittan } \\
\text { kizhangu) }\end{array}$ & Asparagus racemosus & Root & 70 \\
\hline 14 & Nilakkumil & Gmelina asiatica $L$. & Root & 70 \\
\hline 15 & Nerunji & Tribulus terrestris $L$. & Root & 70 \\
\hline 16 & Karkhadagaching & Rhus succedanea $L$. & Dried fruit & 70 \\
\hline 17 & Jatikkai & Myristica fragrans Houtt. & Seed & 70 \\
\hline 18 & Anasi poo & Illicium verum & Fruit & 70 \\
\hline 19 & Shindilakodi & $\begin{array}{l}\text { Tinospora cordifolia } \\
\text { (Willd.) Miers }\end{array}$ & Processed root powder & 60 \\
\hline 20 & Inji (dried) & Zingiber officinale & Rhizomes & 10 \\
\hline 21 & Tippali & Piper longum $L$. & Dried berries & 10 \\
\hline 22 & Ashwagandha & Withania Somnifera & Root & 10 \\
\hline 23 & $\begin{array}{c}\text { Aruruttukkizhangu (Kukai } \\
\text { niru) }\end{array}$ & Maranta arundinaceae & Processed root powder & 60 \\
\hline 24 & Pacchai karpooram & $\begin{array}{c}\text { Camphor or borneol } \\
\text { camphor }\end{array}$ & Camphor crystal & 70 \\
\hline 25 & Milagu & Piper nigrum & Dried fruit & 10 \\
\hline 26 & Vilamichaiver & Plectranthus vettiveroides & Root & 70 \\
\hline
\end{tabular}
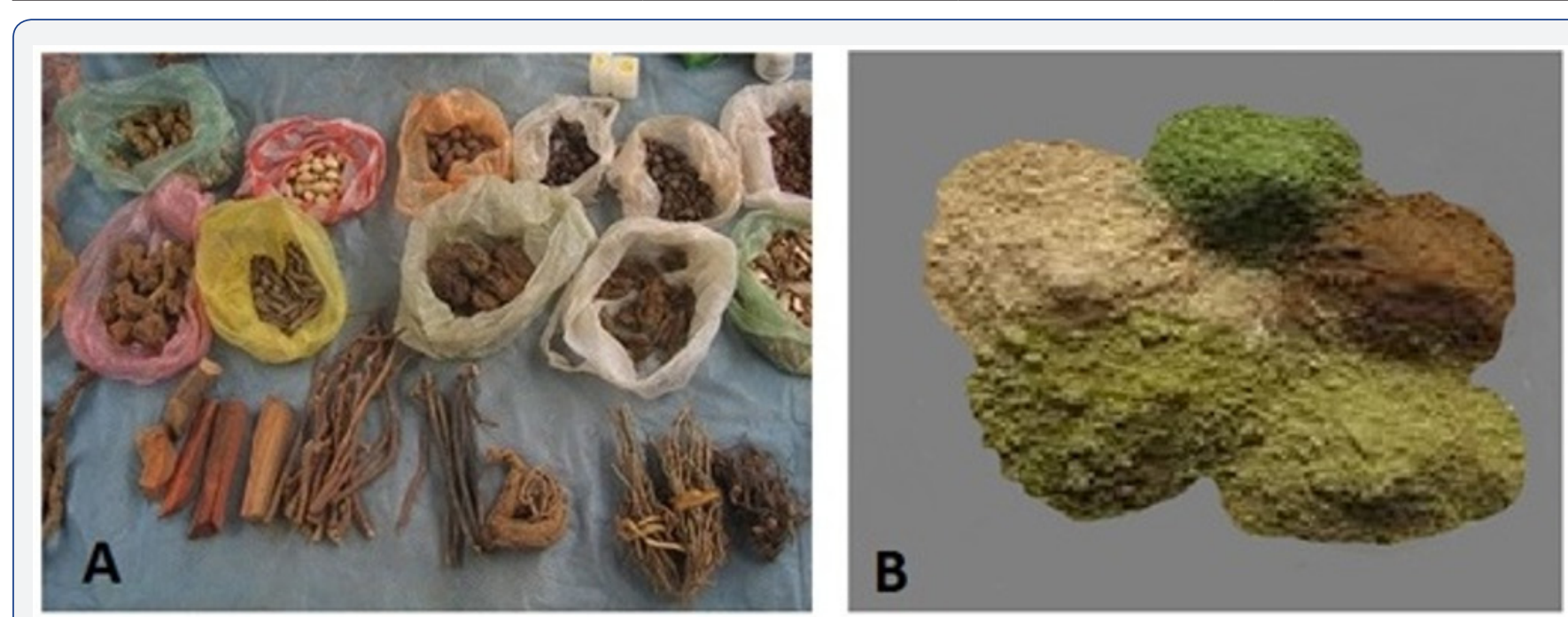

Figure 1: The ingredients of herbal plants for preparation of Amirthathi churnam.

\section{Preparation of Nandukal chunnam}

In Siddha medicine system, varieties of cornucopia of different dosage forms of herbo-mineral formulations are used for healing diseases. Chunnam is one of the highly acclaimed dosage forms of alkaline group of drugs indicated for chronic diseases [10]. Nandukal chunnam is a comprehensive medicine in Siddha treatment methods which is used for urinary tract diseases. It is an indicative product made up of alkaline similar to lime (caustic lime is known as chunnam). The word chunnam is derived from two words such as colour (chum) and lime (chunnam). The Nuandukkal chunnam is prepared from the powdered materials of fossil stone crab (calcium form) using pooneeru and lime water (Figure 2). Then the Aloe vera latex is mixed with the ingredients to produce the calcinated powder according to the specifications given in the Agasthiar Nandukal Sootheram (Ancient Tamil palm leaf literature). The naturally obtained ingredients are processed sequentially like grinding, melting, triturating and quenching in different plant juices in order to produce then into bio-available form. The dosage form of chunnam consists of higher medicament characteristics than parpam (calcified oxide form) and chenduram (sulphide form) dosage drugs [8]. 


\section{Journal of Complementary Medicine \& Alternative Healthcare}
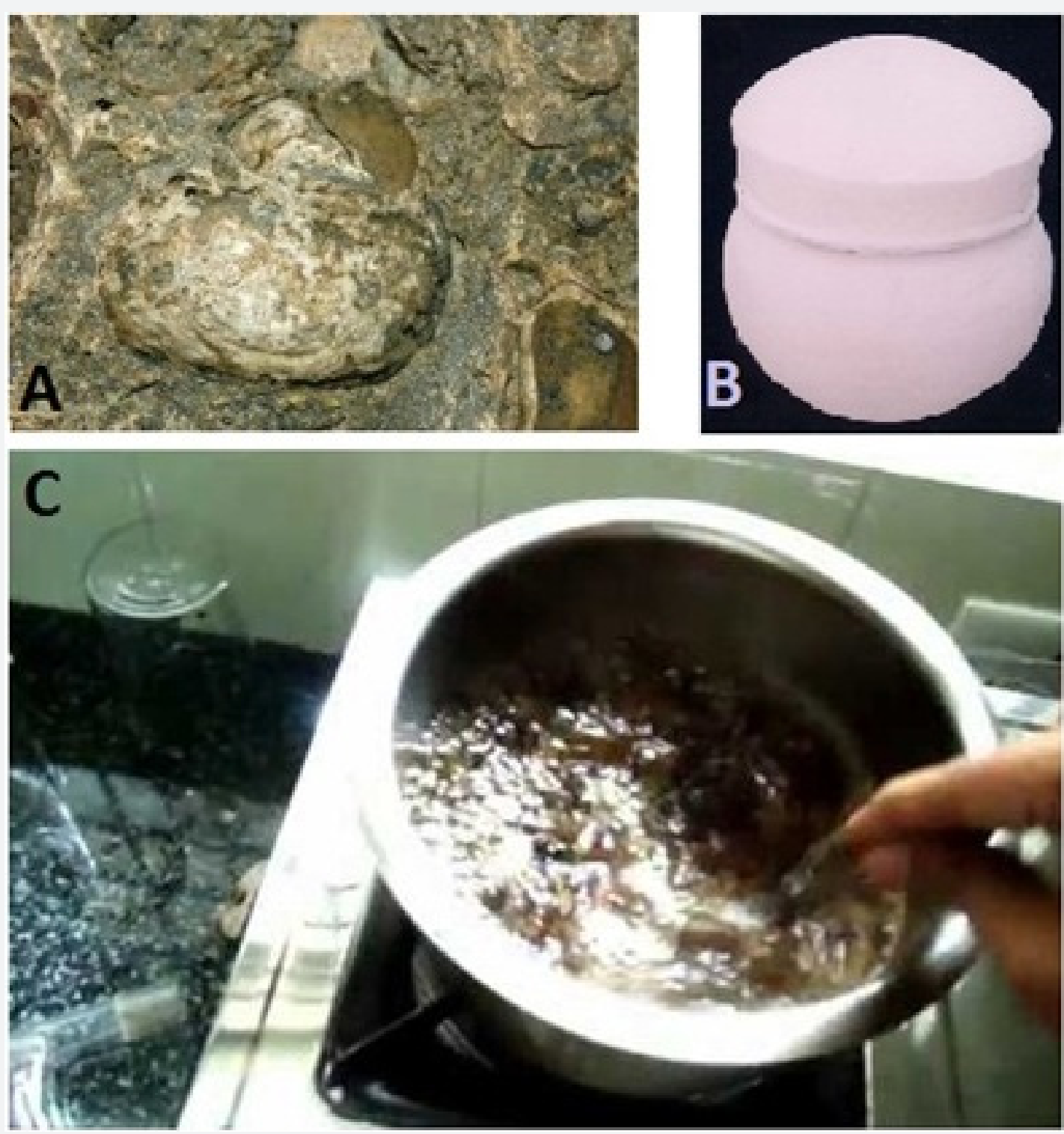

Figure 2: The process of Nandukal chunnam preparation,

a) Nuandukkal (fossil);

b) Purification of Nuandukkal using Calcium coated mud pod;

c) Preparation of chunnam paste according to the Tamil medicine formulation written in palm leaves.

\section{Organoleptic evaluation}

Amirthathi churnam and Nuandukkal chunnam were standardized based on their organoleptic characters, physical Results and Discussion characters and physico-chemical properties. It refers the evaluation of the formulation by colour, odour, taste and texture etc.

\section{Physico-chemical investigations}

Table 2: The major physical properties of Amirthathi churnam and Nuandukkal Chunam.

\begin{tabular}{|c|c|c|c|}
\hline Sl. No. & Particulars & Amirthathi churnam & Nuandukkal chunnam \\
\hline 1 & Colour & Colourless & Colourless \\
\hline 2 & Texture & Fine & Fine \\
\hline 3 & Odour & Not characterized & Not characterized \\
\hline 4 & Taste & Slightly astringent & Slightly astringent \\
\hline
\end{tabular}


Detailed physico-chemical study of Amirthathi churnam and Nuandukkal chunnam have been carried out and the results are shown in Table 2. Chemical analysis of the drugs made up of Amirthathi churnam and Nuandukkal chunnam is performed by testing 5 grams of each of the samples together that incinerated at 450

oC in silica crucibles till there is no evaluation of smoke. The ash obtained is heated in muffle furnace at $800 \mathrm{oC}$ and done post treatment with Con. H2SO4 and ignition. These samples further are dissolved in $100 \mathrm{ml}$ dil. $\mathrm{HCl}(1: 20)$. The solution is transferred to polyethylene bottle and used for determination of metal concentration in the drug by based on the standard procedure of HG-ET-AAS measurements adopted by Ajasa et al. [5] using AAS (Atomic Absorption Spectro-photometry) instrument (PerkinElmer PinAAcle model 900Z (longitudinal Zeeman system), Ohio, USA). The concentrated acids used were of analytical reagent grade of GFS chemicals, Inc. Columbus. Stock standard solutions of $\mathrm{Zn}, \mathrm{Cu}, \mathrm{Fe}, \mathrm{Mn}, \mathrm{Cd}, \mathrm{Co}, \mathrm{Ni}, \mathrm{As}, \mathrm{Hg}, \mathrm{Cr}$ and $\mathrm{S}$ containing $1000 \mathrm{ppm}$ of each metal were used. The calibration for each element standards were obtained by required dilution of the stock solutions. The analytical results of chemical contents such as heavy metals and trace elements are given in Table 3.

Table 3: Trace element contents in the drugs made up of Amirthathi churnam and Nandukal chunam.

\begin{tabular}{|c|c|c|c|}
\hline Sl. No & Metals & Results & $\begin{array}{c}\text { ADI limits of } \\
\text { WHO }\end{array}$ \\
\hline 1 & $\mathrm{~S}$ & $30.40 \%$ & -- \\
\hline 2 & $\mathrm{As}$ & $0.68 \mathrm{mg} / \mathrm{L}$ & $0.01 \mathrm{mg} / \mathrm{L}$ \\
\hline 3 & $\mathrm{Cu}$ & $0.72 \mathrm{mg} / \mathrm{L}$ & $2.00 \mathrm{mg} / \mathrm{L}$ \\
\hline 4 & $\mathrm{Cd}$ & $0.01 \mathrm{mg} / \mathrm{L}$ & $0.03 \mathrm{mg} / \mathrm{L}$ \\
\hline 5 & $\mathrm{Fe}$ & $28.17 \mathrm{mg} / \mathrm{L}$ & $0.3 \mathrm{mg} / \mathrm{L}$ \\
\hline 6 & $\mathrm{Co}$ & $0.35 \mathrm{mg} / \mathrm{L}$ & $0.005 \mathrm{mg} / \mathrm{L}$ \\
\hline 7 & $\mathrm{Mn}$ & $2.76 \mathrm{mg} / \mathrm{L}$ & $0.5 \mathrm{mg} / \mathrm{L}$ \\
\hline 8 & $\mathrm{~Pb}$ & $0.85 \mathrm{mg} / \mathrm{L}$ & $0.01 \mathrm{mg} / \mathrm{L}$ \\
\hline 9 & $\mathrm{Zn}$ & $0.26 \mathrm{mg} / \mathrm{L}$ & $3.00 \mathrm{mg} / \mathrm{L}$ \\
\hline 10 & $\mathrm{Ni}$ & $0.98 \mathrm{mg} / \mathrm{L}$ & $0.02 \mathrm{mg} / \mathrm{L}$ \\
\hline 11 & $\mathrm{Hg}$ & $0.44 \mathrm{mg} / \mathrm{L}$ & $0.001 \mathrm{mg} / \mathrm{L}$ \\
\hline 12 & $\mathrm{Cr}$ & $1.47 \mathrm{mg} / \mathrm{L}$ & $0.05 \mathrm{mg} / \mathrm{L}$ \\
\hline
\end{tabular}

\section{Clinical evaluation}

The present study was conducted to evolve the efficacy of the Siddha proprietary drug to treat patients of Nephrolithiasis.
The 20 diagnosed patients of Nephrolithiasis were identified and treatment carried out in Siddha consulting center, Nagarcoil by Dr. Eliza. The details of dosage given to the patients are Amirthathi churnam 2.5gm and Nuandukkal chunnam 0.5gm with milk in two times daily. The adjuvant for the drug is water or cow milk and the route of administration is oral or entral. All the patients were investigated for urinal function, cyst, crystal pus cell in urine and ultra scan to measure the nature of the stone. The selected and treatment patients were grouped into the following categories include $15-25 ; 26-35$; 36-45; 46-55; 5665; 66-75 and above 75 having male and female (Table 4). The treatment both Amirthathi churnam and Nuandukkal chunnam exhibited significant Nephrolithiasis activity by reducing the symptom of burning micturition, dysuria, hematuria, abdominal pain from loin to groin, back pain and general symptoms like nausea and vomiting in the first 15 days of treatment and other symptoms gradually subsided in the remaining course of treatment. Further, the potency of the drug was evaluated by pharmacological analysis and the results of that on urinary calcium oxalate and phosphate components are given in Table 5. The clinical treatment of the patients is recovered significantly from the symptoms of various size of calculi of Nephrolithiasis include renal calculi, ureteric calculi and vesicle calculi. Similarly ureteric calculi have good response to the test drug (80\%) and renal and vesicle calculi are $77 \%$ and $50 \%$ respectively (Table 6). From this, it observed that the drug has strong actions to the Nephrolithiasis activities. The elemental concentrations in the prepared drug are compared with acceptable daily intake (ADI) limits of WHO, these elements considered that they have strong biological activities and therapeutic importance in the treatment of Nephrolithiasis. The drug has not shown any undesirable side effects and Siddhars have taken great concern for health by providing the safety and quality of traditionally prepared herbo-mineral formulations. Therefore, the clinical treatment of patients with different age categories provides significantly positive results to remove the urinary stones. The $99 \%$ of patients having $0.5 \mathrm{~mm}$ size of the calculi have been recovered, whereas, $75 \%$ of patients recovered from having 6 to $10 \mathrm{~mm}$ (Table 7). But $10 \mathrm{~mm}$ have not shown any results to the drug administration. The distribution of calculi in right and left kidneys of patients were evaluated statistically before and after treatment (Table 8). The treatment of the cases has been graded based on the recovery status. The elemental concentrations in Amirthathi churnam and Nuandukkal chunnam have shown both a curative and a preventive role in combatting the Nephrolithiasis diseases. It is shown therefore of major interest to establishing the recovery gradation of treatment (Table 9). The observations were being tested statistically using one way analysis of variance (ANOVA) method with reference to the age and sex. The male and female with different age categories were taken to compute the "t" values and calculate the significant levels for all the 20 patients. This reveals that the $\mathrm{P}>0.05$ was considered significant between 28.6 to 47.2 years of the patients. This confirmed the efficacy of the drug administration (Table 10). 
Table 4: The status of patients with age category for treatment of nephrolithiasis.

\begin{tabular}{|c|c|c|c|c|}
\hline Sl. No. & Age & Male & Fotal \\
\hline & & 1 & 2 & 3 \\
\hline 1 & $15-25$ & 2 & - & 2 \\
\hline 3 & $26-35$ & 6 & - & 8 \\
\hline 4 & $36-45$ & 2 & - & 2 \\
\hline 5 & $46-55$ & 2 & - & 2 \\
\hline 6 & $56-65$ & 2 & - & 2 \\
\hline 7 & $66-75$ & 1 & & 2 \\
\hline
\end{tabular}

Table 5: Pharmacological analysis of the drug on urinary calcium oxalate and phosphate components.

\begin{tabular}{|c|c|c|c|c|}
\hline Sl. No & Treatment & Calcium (mg/L) & Phosphate (mg/L) & Oxalate (mg/L) \\
\hline 1 & Control (vehicle) & \pm 0.41 & $47.34 \pm 3.8$ & $4.39 \pm 0.33$ \\
\hline 2 & Glycolic acid control & $13.37 \pm 0.81$ & $71.93 \pm 5.3$ & $9.6 \pm 0.88$ \\
\hline 3 & $\begin{array}{c}\text { Amirthathi choornam and } \\
\text { Nandukal Chunnam (100 } \\
\mathrm{mg} / \mathrm{kg})\end{array}$ & $8.83 \pm 0.71$ & $49.47 \pm 3.8$ & $5.31 \pm 0.28$ \\
\hline 4 & $\begin{array}{c}\text { Amirthathi choornam and } \\
\text { Nandukal Chunnam (200 } \\
\mathrm{mg} / \mathrm{kg})\end{array}$ & $8.02 \pm 0.78$ & $48.01 \pm 3.3$ & $4.52 \pm 0.38$ \\
\hline
\end{tabular}

Table 6: the percentage of recovery of different types of calculi in the patients.

\begin{tabular}{|c|c|c|c|c|}
\hline Sl. No. & Name of the calculi & No. of cases treated & No. of cases recovered & Percentage of recovery \\
\hline 1 & Renal calculi & 13 & 10 & $77 \%$ \\
\hline 2 & Ureteric calculi & 5 & 4 & $80 \%$ \\
\hline 3 & Vesicle calculi & 2 & 1 & $50 \%$ \\
\hline
\end{tabular}

Table 7: The recovery status of patients before and after the treatment of nephrolithiasis.

\begin{tabular}{|c|c|c|c|c|}
\hline Sl. No. & Size of the calculi & No. of cases treated & No. of cases recovered & Percentage of recovery \\
\hline 1 & $<5 \mathrm{~mm}$ & 10 & 9 & $99 \%$ \\
\hline 2 & $6 \mathrm{~mm}-10 \mathrm{~mm}$ & 8 & 6 & $75 \%$ \\
\hline 3 & $>10 \mathrm{~mm}$ & 2 & - & - \\
\hline
\end{tabular}

Table 8: The size of calculi in left and right kidneys before and after treatment of nephrolithiasis.

\begin{tabular}{|c|c|c|c|c|c|c|c|}
\hline Sl. No. & Kidney & No. of patients. & $\begin{array}{c}\text { Calculi before } \\
\text { treatment }\end{array}$ & $\begin{array}{c}\text { Calculus after } \\
\text { treatment }\end{array}$ & $\begin{array}{c}\text { Mean } \\
\text { Differences }\end{array}$ & “t” & Significance \\
\hline 1 & Right Kidney & 20 & 3.572 .95 & 0.551 .7 & 3.02 & 4.43 & $\mathrm{P}<0.00$ \\
\hline 2 & Left Kidney & 20 & 2.713 .67 & 1.303 .2 & 1.41 & 2.83 & $\mathrm{P}<0.01$ \\
\hline
\end{tabular}

Table 9: The results of gradation of the treatment of nephrolithiasis.

\begin{tabular}{|c|c|c|c|}
\hline Sl. No. & Result & No. of Cases & Percentage \\
\hline 1 & Good & 15 & $75 \%$ \\
\hline 2 & Fair & 4 & $20 \%$ \\
\hline 3 & Poor & 1 & $5 \%$ \\
\hline
\end{tabular}

Table 10: Biostatistical analysis of the patients with different age categories.

\begin{tabular}{|c|c|c|c|c|c|c|c|}
\hline SI. No. & Sex & No. of patients & \multicolumn{2}{|c|}{ Age } & “t” & $\begin{array}{c}\text { Significant } \\
\text { Level }\end{array}$ & $\begin{array}{c}\text { 95 \% CL of the } \\
\text { population }\end{array}$ \\
\hline 1 & Male & 16 & 41.5 & 19.83 & 1.7 & P > 0.05 & \\
\hline 2 & Female & 4 & 23.5 & 13.43 & & & \\
\hline & Total & 20 & 37.9 & 19.83 & - & - & 28.6 to 47.2 years \\
\hline
\end{tabular}




\section{Conclusion}

It is observed that Amirthathi churnam and Nuandukkal chunnam are having good response to reduce the size of the calculi. After having treatment, the patients have been found with non-recurrent condition. On the basis of clinical observation, the Amirthathi churnam and Nuandukkal chunnam in Siddha formulations are considered to be safe for treating the Nephrolithiasis diseases which has been clearly substantiated in the clinical evaluation and more authentication of the claim mentioned in the traditional literature. However, the mode of action of the drugs has to be standardized based on the histopathological analysis in progress.

\section{Acknowledgement}

The Authors are thank to S. Kaliraj, Research Scholar (DSTINSPIRE Fellow SRF), Centre for Geo Technology, Manonmaniam Sundaranar University, Tirunelveli for his support in the laboratory analysis and the preparation of manuscript.

\section{Conflicts of Interest}

The authors and contributors of this work declare no conflict of interest.

\section{References}

1. Uddhamaraayan KS (1983) Siddha Maruthuvaanga Churukkam (in Tamil), Chennai, Tamil Nadu; Siddha Medical Board Publication.

2. Kuppusamy Mudaliyar KN (1987) Siddha Maruthuvan (in Tamil), Chennai, India: Tamil Nadu Siddha Medical Board Publication.

3. Rignell-Hydbom A, Kerfving S, Lundh T, Lindh CH, Elmstahl S, et al. (2009) Exposure to cadmium and persistent organochlorine pollutants and its association with bone minerals density and markers of bone metabolism on postmenopausal women. Environmental Research 109(8): 991-996.

4. Chen X, Zhu G, Jin T, Gu S (2009) Effects of cadmium on forearm bone density after reduction of exposure for 10 years in a Chinese population. Environment International 38(8):1164-1168.

5. Ajasa AMO, Bello MO, Ibrahim AO, Ogunwande IA, Olawore NO (2004) Heavy trace metals and macronutrients status in herbal plants of Nigeria. Food Chemistry 85: 67-71.
6. Sidhu JS, Gill MS, Bains GS (1975) Milling of paddy in relation to yield and quality of rice of different Indian varieties. Journal of Agricultural and Food Chemistry 23(6): 1183-1185.

7. Bagul MS, Rajani M (2005) Phytochemical evaluation of classical formulation - A case study. Indian Drugs 42(1): 15-19.

8. Muthukumar B (2009) Study on efficacy of Siddha drugs (CL and CEN) in rheumatoid arthritis. Indian J Traditional Knowledge 8(3): 446-448.

9. Rakesh RS (2013) Efficacy of Malati Kashtha Churna (Jasminum officinale L) for Dantadhavana. International Journal of Advanced Ayurveda, Yoga, Unani, Siddha and Homeopathy 2(1):33-45.

10. Ayyasamy S, Sudha R (2013) Chunnam: A commended dosage form in Siddha medicine. International J Research in Ayurveda and Pharmacy 4(1): $1-4$.

11. Neeraj K, Sriwastava C, Shreedhara S, Aswatha Ram HN (2010) Standardization of Ajmodadi churna, a polyherbal formulation. Pharmacognosy Res 2(2): 98-101.

12. Makhija IK, Shreedhara CS, Ram HH (2012) Physico-chemical standardization of Sitopaladi churna. Anc Sci Life 31(3): 107-116.

13. Patel KN (1996) Solutions to problems associated with herbal drugs and their formulations. Pharma Plus 1(1): 9-11.

14. Eapen Saumy MS, Grampurohit ND (2002) Chemical evaluation of Navayasa churna. Indian Drugs. 39(2):101-105.

15. (1996) International Conference on Harmonization (ICH) of Technical Requirements for the Registration of Pharmaceuticals for Human Use, Validation of analytical procedures: Methodology, ICH-Q2B, Geneva.

16. Somers E (1983) The toxic potential of trace metals in foods - A review. Journal of Food Science 39: 215-217.

17. Schumacher M, Bosque MA, Domingo JL, Corbella J (1991) Dietary intake of lead and cadmium from foods in Tarragona Province, Spain Bulletin of Environmental Contaminant and Toxicology 46(2): 320328

18. Jeganathan NS, Kannan K, Manavalan R, Vasanthi HR (2008) Standardization of a Siddha formulation Amukkara curanam by HPTLC. Afr J Trad. CAM 5(2): 131-140.

19. Nair RB, Nair KV, Nair AR. Nair CPR (1992) Antidiabetic activity of Amrithadi churnam. Anc Sci Life 12(1-2): 280-285.

20. (1992) The Siddha Formulary of India (Part I) (1 $1^{\text {st }}$ edn,). New Delhi, India; Department of Health, Ministry of Health and Family Welfare, Govt. of India.

21. World Health Organization (2005) Quality Control Methods for Medicinal Plant Materials (revised). WHO publications, Geneva.

\section{Your next submission with Juniper Publishers} will reach you the below assets

- Quality Editorial service

- Swift Peer Review

- Reprints availability

- E-prints Service

- Manuscript Podcast for convenient understanding

- Global attainment for your research

- Manuscript accessibility in different formats

( Pdf, E-pub, Full Text, Audio)

- Unceasing customer service

Track the below URL for one-step submission https://juniperpublishers.com/online-submission.php 